\title{
TAJEMNICE JEZUSA CHRYSTUSA W ROKU LITURGICZNYM A „ŚWIĘTA PODRÓŻ”. ANALIZA WYBRANYCH PISM CHIARY LUBICH
}

\author{
THE MYSTERIES OF JESUS CHRIST IN THE LITURGICAL YEAR \\ AND THE „HOLY JOURNEY”. \\ ANALYSIS OF SELECTED WRITINGS BY CHIARA LUBICH
}

\begin{abstract}
A b s t r a c t. From 1981 until 2004, Chiara Lubich shared her spiritual experience with the members of the Focolare Movement in regular telephone conferences, inviting them to walk to holiness together, as the psalmist said: "Blessed are those whose strength is in you, whose hearts are set on pilgrimage" (Ps 84: 6). The purpose of this article is to analyse these messages in relation to the periods of the liturgical cycle they cite, and to determine to what extent the contemplation of the mysteries of Jesus Christ throughout the year can influence the process of becoming more fully conformed to Him.
\end{abstract}

Keywords: Chiara Lubich; liturgical year; holy journey; telephone conferences.

„Szczęśliwi, którzy od Ciebie otrzymują pomoc, gdy świętą podróż odbyć zamierzyli w sercu" (Ps 84,6) ${ }^{1}-$ w tych słowach psalmisty Chiara Lubich ${ }^{2}$

KATARZYNA WASIUTYŃSKA - doktor teologii, współpracuje z Zakładem Teologii Systematycznej na Wydziale Teologicznym UAM w Poznaniu; adres do korespondencji: ul. Kazimierza Wielkiego 31/2, 30-074 Kraków; e-mail: kwasiutynska@gmail.com; ORCID: https://orcid.org/0000-0002-1468-3370.

${ }^{1}$ Przywołane tłumaczenie Stanisława Wójcika CSSR (por. Księga Psalmów, Wrocław 1947) jest najbliższe tekstu włoskiego, używanego przez Lubich: „Beato chi trova in te la sua forza e decide nel suo cuore il santo viaggio". W innych tłumaczeniach nie pojawia się pojęcie „podróż”. Według IV wydania Biblii Tysiąclecia werset ten brzmi: „Szczęśliwi, których moc jest w Tobie, którzy zachowują ufność w swym sercu" (w przypisach widnieje informacja, że tekst $\mathrm{w}$ przekładzie $\mathrm{z}$ hebrajskiego został poprawiony). 
znalazła szczególną wskazówkę dla swojego życia duchowego, kiedy rozważała drogę do świętości typową dla duchowości Focolari ${ }^{3}$. Stały się one także impulsem do wprowadzenia nowej praktyki wspólnotowej, ukierunkowanej na wzajemne zbudowanie, która w formie światowej konferencji telefonicznej towarzyszyła wszystkim członkom Ruchu przez ponad dwadzieścia lat, od roku 1981 aż do ostatniego okresu życia Założycielki.

Niniejsza refleksja odczytuje teksty będące zapisem tego doświadczenia Chiary - dzielonego regularnie z innymi - z perspektywy roku liturgicznego, aby określić wpływ rozważanych przez Kościół tajemnic wiary na dynamikę życia duchowego w jego wymiarze osobistym. Wychodzi od samego pojęcia „Święta podróż”, które w pismach Lubich nabrało specyficznego znaczenia, w kontekście procesu uświęcenia na drodze wspólnotowej. Następnie, wśród odnoszących się do niego tekstów duchowych, rozpatruje te, które w sposób bezpośredni lub pośredni nawiązują do poszczególnych świąt i okresów roku liturgicznego. Ostatnia część poświęcona jest charakterystycznym rysom duchowości Chiary, jeśli chodzi o kontemplację tajemnic Jezusa Chrystusa na drodze coraz pełniejszego upodobnienia się do Niego.

\section{POJĘCIE „ŚWIEcTEJ PODRÓŻY”W HISTORII RUCHU FOCOLARI}

Latem roku 1980, z perspektywy niemal czterdziestu lat istnienia Focolari ${ }^{4}$ - które odzwierciedlają wiernie osobiste doświadczenie duchowe Założycielki - z myślą o członkach Ruchu przygotowuje ona na piśmie obszerną refleksję nad wypełnianiem woli Bożej. Temat ten jest obecny od samego

${ }^{2}$ Chiara Lubich (1920-2008) - Włoszka, założycielka rozpowszechnionego na całym świecie Ruchu Focolari (oficjalna nazwa: Dzieło Maryi). W roku 2015 rozpoczął się jej proces beatyfikacyjny.

${ }^{3} \mathrm{Na}$ temat procesu uświęcenia charakterystycznego dla duchowości Chiary Lubich por. m.in. Gérard Rossé, ,Santità e santificazione negli scritti di Chiara Lubich alla luce di S. Paolo”, Nuova Umanità 19(1997), 3-4: 377-386; Katarzyna Wasiutyńska, „Święty pomiędzy nami... Ruch Focolari”, Duchowość w Polsce 14(2012): 90-96; Lucia Abignente, „SANTI PER AMORE, SANTI CON GLI ALTRI. Il cammino alla santità nel pensiero e nella testimonianza di Chiara Lubich”, Duchowość w Polsce 14(2012): 287-300; Lucia Abignente, „La santità nel pensiero e nella testimonianza di Chiara Lubich", Nuova Umanità 25(2013), 2: 153-174.

${ }^{4}$ Za oficjalną datę początku Ruchu Focolari uznaje się 7 grudnia 1943 roku: dzień, w którym Chiara Lubich poświęciła się Bogu, składając ślub czystości. Nie myślała w żaden sposób o założeniu nowego dzieła w Kościele, ale już w ciągu kilku miesięcy w jej rodzinnym Trydencie powstała spora grupa osób, pociągniętych jej ewangelicznym stylem życia. 
początku w duchowości jedności ${ }^{5}$, ale w tamtym okresie Chiara zdaje się rozumieć go w sposób zupełnie nowy i zauważa w sobie samej niezwykłe owoce tego odkrycia. Przekonuje się, że zdecydowane wypełnianie woli Bożej może stać się dla wszystkich drogą do świętości. Wierna duchowości wspólnotowej, dzieli się nieustannie swoimi wewnętrznymi odkryciami i intymnym doświadczeniem Boga z pozostałymi członkami Ruchu, z fokolarinami ${ }^{6}$ oraz z młodymi, z którymi łączy ją zupełnie szczególna więź. 31 grudnia 1980 roku zachęca tych ostatnich do podjęcia wraz z nią przyspieszonej drogi do świętości, widząc w bezwarunkowej miłości do Jezusa opuszczonego ${ }^{7}$ pewne źródło cnót heroicznych ${ }^{8}$. To przynaglenie, które Chiara odczytuje najpierw jako dar Boga dla jej osobistego życia, szybko staje się drogowskazem dla całej jej duchowej rodziny. Proces ten dokonuje się w sposób naturalny, gdyż w Ruchu od samego początku praktykuje się dzielenie dobrami duchowymi, podobnie jak materialnymi, a troska o świętość drugiego jak o własną rozumiana jest jako konkretny wyraz braterskiej miłości.

Historycznie ten okres przyspieszenia duchowej drogi do doskonałości zbiega się z nową możliwością komunikacji między poszczególnymi wspólnotami focolare. W tym samym czasie, latem 1980 roku, Lubich znajduje się w Szwajcarii i tradycyjnie w dniu św. Klary spotyka się z członkami Ruchu przybyłymi na tę okazję z różnych miast. Spontanicznie rodzi się wówczas pragnienie, aby pozostać w jak najbliższym kontakcie i dzielić się wiadomościami oraz doświadczeniem duchowym poszczególnych wspólnot. Wszystko zaczyna się od regularnych połączeń telefonicznych pomiędzy miastami, dwa razy w tygodniu, dzięki możliwości skorzystania z konferencji telefonicznej za pośrednictwem centrali ${ }^{9}$. W krótkim czasie dołączają się do nich gru-

${ }^{5}$ Opisując charakterystyczną dla Ruchu duchowość jedności, Lubich ujmuje ją w dwunastu punktach, które odnoszą się do poszczególnych etapów jego historii i odpowiadających im fragmentów Ewangelii, wprowadzanej w praktykę zdanie po zdaniu. Są to: Bóg-miłość, wola Boża, Słowo Boże, miłość bliźniego, miłość wzajemna, jedność, Eucharystia, Jezus Opuszczony (por. Mk 15,34), Maryja, Kościół, Duch Święty, Jezus obecny pośród „dwóch lub trzech” (por. Mt 18,20). Por. Dzieło Maryi, Statuty Generalne, art. 8.

${ }^{6}$ To określenie w sensie ścisłym odnosi się do świeckich osób konsekrowanych, na wzór Chiary, żyjących w małych wspólnotach zwanych focolare.

${ }^{7}$ Imię ,Jezus opuszczony” odnosi się do wołania Jezusa na krzyżu: „Boże mój, Boże mój, czemuś Mnie opuścił?” (Mk 15,34), w którym Lubich widzi szczyt Jego miłości. Poruszona miarą Jego cierpienia, wybiera Opuszczonego jako jedynego Oblubieńca swojego życia.

8 Por. Chiara Lubich, Michel Vandeleene, Conversazioni in collegamento telefonico. (Roma: Città Nuova, 2019), 691.

${ }^{9}$ Konferencje te odbywają się początkowo dzięki szwajcarskim liniom Swisscom i z tego względu przyjmuje się ich nazwa: Collegamento (z wł. połączenie) $\mathrm{CH}$ (Confoederatio Helveti- 
py z innych krajów, w październiku tego samego roku wśród odbiorców są już przedstawiciele Brazylii, Peru, Kolumbii, Meksyku i Filipin ${ }^{10}$. W pierwszych latach konferencje odbywają się raz na dwa tygodnie, a od roku 1990, kiedy technicznie staje się możliwe połączenie blisko stu punktów jednocześnie, raz w miesiącu.

Te planetarne spotkania wspólnot Ruchu, trwające najpierw od 12 do 20 minut, a później około godziny, składają się z dwóch części. Pierwsza z nich to myśl duchowa Chiary, w której, wychodząc zazwyczaj od osobistego doświadczenia, zachęca ona wszystkich do podążania razem droga jedności ${ }^{11}$, druga natomiast zawiera wybrane wiadomości z życia Ruchu w świecie. W roku 2019 wydano w języku włoskim zbiór wszystkich tych tekstów w tomie Conversazioni in collegamento telefonico: jest ich łącznie 280. Pierwszy z nich, opatrzony datą 3 września 1981 roku, nosi znaczący tytuł: „Święta podróż"12. Ostatni pochodzi z 23 września 2004 roku i już w pierwszym zdaniu nawiązuje do tego samego motywu: „oto nasze wrześniowe połączenie telefoniczne, którego celem - podobnie jak wszystkich [...] od ponad dwudziestu lat - jest pomóc nam uczynić życie Świętą Podróżą, to znaczy doprowadzić nas do świętości" "13. Wspomniane myśli duchowe, przygotowane uprzednio na piśmie, a później przesyłane do wszystkich członków Focolari stanowią zupełnie oryginalny, chronologicznie precyzyjny zapis drogi Chiary do świętości.

ca). Por. Giulia Folonari, Lo spartito scritto in cielo: cinquant'anni con Chiara Lubich (Roma: Città Nuova, 2012), 84.

${ }^{10}$ Lubich, Vandeleene, Conversazioni in collegamento telefonico, 9.

${ }^{11} \mathrm{Na}$ temat pedagogicznego znaczenia konferencji telefonicznych por. Maria José Dantas, „Pedagogia Chiary Lubich w «Myślach duchowych konferencji telefonicznych Collegamento CH»”, Paedagogia Christiana 43(2019), 1: 279-295.

12 „Powodem, który mnie skłania, aby zwrócić się do was, jest pragnienie, abyśmy wspólnie zobaczyli, jak wygląda sprawa naszej świętości. W tych dniach jedna z fokolarin zwróciła moją uwagę na piękne zdanie z Psalmów, zawierające błogosławieństwo, którego nie znałam: «Szczęśliwi, którzy od Ciebie otrzymują pomoc, gdy świętą podróż odbyć zamierzyli w sercu» (Ps 84,6). «Święta podróż». O jakiej podróży mówi Pismo? Na pewno o drodze człowieka do Boga, do Nieba, a więc o drodze do uświęcenia się, które otwiera nam Niebo. Tę decyzję o rozpoczęciu Świętej Podróży podjęliśmy wszyscy, kiedy odpowiedzieliśmy na nasze powołanie: być fokolarinami [przesłanie skierowane jest do konsekrowanych członków wspólnot focolare]. Rzeczywiście, dla nas - ponieważ jesteśmy poświęceni Bogu - dążenie do doskonałości jest zadaniem zobowiązującym nas bardziej niż innych. A więc? Czy ruszyliśmy w Świętą Podróż i teraz idziemy nią dalej?” Lubich, Vandeleene, Conversazioni in collegamento telefonico, 61 .

${ }^{13}$ Lubich, Vandeleene, Conversazioni in collegamento telefonico, 681. 
Bez wątpienia to bogate dziedzictwo duchowe Założycielki nie ogranicza się do pism przygotowanych na konferencje telefoniczne. Przez wszystkie te lata prowadzi ona aktywne życie apostolskie i niemal każde spotkanie stanowi dla niej okazję do podzielenia się doświadczeniem chrześcijańskim przeżywanym w świetle charyzmatu jedności. Ponadto, prowadzi w pewnych okresach dziennik duchowy ${ }^{14}$, a także niemal co roku przygotowuje rozbudowaną refleksję poświęconą podstawowym elementom duchowości, przeznaczoną dla formacji członków. Charakterystyczną i regularną praktyką jest, obok myśli duchowych odczytywanych podczas konferencji telefonicznych, comiesięczny komentarz do wybranego zdania z Pisma Świętego, nazywanego Słowem życia. Poza drobnymi wyjątkami, sama Chiara od lat czterdziestych aż po rok 2004, przygotowuje to ewangeliczne objaśnienie ${ }^{15}$. Wiele $z$ nich odnosi się również do poszczególnych wydarzeń roku kościelnego, do Liturgii Słowa, a w myśli duchowej odczytywanej podczas konferencji telefonicznych pojawiają się nierzadko nawiązania do poszczególnych Słów życia. Ze względu na ramy objętościowe i tematyczne niniejszego artykułu, ogranicza się on do analizy pism przygotowywanych na światowe połączenia, które wyznaczają bezpośrednio rytm „świętej podróży” Chiary i jej duchowej rodziny.

\section{ELEMENTY ROKU LITURGICZNEGO W WYBRANYCH PISMACH CHIARY LUBICH}

Celem regularnych konferencji telefonicznych łączących wszystkie wspólnoty Ruchu jest rozbudzić, podtrzymać i udoskonalić dążenie do świętości, w wymiarze osobistym oraz wspólnotowym, zgodnie z charyzmatem jedności. Spotkania te są regularne, możliwie częste, ale nie podlegają ścisłemu rygorowi czasowemu i zdarzają się okresy przerw. Konkretne terminy zależą od aktualnych okoliczności, od programów osobistych Chiary oraz całego Ruchu. Z tego względu zbieżność z poszczególnymi okresami i świętami liturgiczny-

${ }^{14}$ Jedyna opublikowana w całości część dziennika duchowego Chiary obejmuje lata 196465. Por. Chiara Lubich, Diario 1964/65 (Roma: Città Nuova, 1985). Inne jego fragmenty znaleźć można w licznych tematycznych zbiorach pism, natomiast w Archiwum Ruchu Focolari znajdują się również zapiski z dziennika z lat: 1966, 1968, 1971, 1972, 1973, 1977, 1979, 1980, 1981, 1983, 1991.

${ }^{15}$ W roku 2017 wydano wszystkie (316) komentarze do Słów życia, jakie Lubich napisała na przestrzeni lat 1943-2006, por. Chiara Lubich, Fabio Ciardi, Parole di Vita (Roma: Città Nuova, 2017). 
mi jest rozmaita. Różny jest też stopień nawiązania do nich: czasem jest to pojedyncze zdanie lub akapit, wskazujący jedynie na kontekst głównej myśli. Innym razem motyw liturgiczny staje się osią, wokół której Chiara buduje całą myśl. Zawsze jednak medytacja danej tajemnicy pobudza do konkretnych postanowień, wpisuje się w aktualne życie i działanie w różnych aspektach. Warto jeszcze zaznaczyć, że najwięcej odniesień, bezpośrednich i pośrednich, do poszczególnych świąt znajduje się w pierwszym dziesięcioleciu, to znaczy w latach 1981-1990. Biorąc pod uwagę, że częstotliwość połączeń w tym okresie jest dwukrotnie, a czasem nawet trzykrotnie większa niż później, można łatwo zrozumieć, że zbieżność dat i motywów liturgicznych jest wówczas o wiele bardziej prawdopodobna. Tym niemniej w niniejszej analizie pisma te zostają odczytane według porządku roku liturgicznego, a nie chronologicznie.

Adwent pojawia się w rozpatrywanych tekstach trzy razy w formie odrębnej od Narodzenia Pańskiego. W 1982 roku Chiara nawiązuje do Słowa życia: „Przygotujcie drogę Panu, dla Niego prostujcie ścieżki” (Mk 1,3) i zachęca, aby uczynić to przede wszystkim na sposób typowy dla duchowości Focolari: „który upewnia nas, że idziemy właściwą drogą, prowadząca na pewno do celu - do Boga. Jest w niej konieczne przejście, a nazywa się ono: brat. Zacznijmy znowu w tym miesiącu kochać ze wszystkich sił każdego brata, którego spotykamy w ciągu dnia [...]. Będziemy mogli w ten sposób przygotować na Boże Narodzenie jako dar dla przychodzącego Jezusa, nasz owoc soczysty i bogaty, a nasze serce płonące i przemienione przez miłość"16. W 1985 roku, także w nawiązaniu do aktualnego Słowa życia (1 Tes 3,12), stwierdza: „Chciałabym wam i sobie życzyć, w duchu św. Pawła, by nasza wspólnota rozsiana po całym świecie wzrosła w tym miesiącu i obfitowała miłością tak, żeby naprawdę uradować Jezusa w Niebie, by mógł On powiedzieć: to jest najpiękniejsze Boże Narodzenie od czasu, kiedy przyszedłem na ziemię"17. Natomiast w 1986 roku zachęca swoich słuchaczy: „W ciągu najbliższych dwóch tygodni stawiajmy nadal w centrum naszego życia miłość do bliźniego i miłość wzajemną. Będzie to najlepszy sposób przygotowania się do Adwentu, tego okresu w roku, w którym przygotowujemy się na przyjście Pana. Dzięki tej miłości Jezus odrodzi się w nas i pomiędzy nami" ${ }^{18}$. Czas Adwentu jest zatem dla Chiary zawsze przynagleniem do ożywienia

\footnotetext{
${ }^{16}$ Lubich, Vandeleene, Conversazioni in collegamento telefonico, 100.

17 Tamże, 223.

18 Tamże, 263.
} 
miłości braterskiej, gdyż to ona oczyszcza z egoizmu i różnych słabości, otwierając w ten sposób duszę na spotkanie z Bogiem.

Narodzenie Pańskie jest zdecydowanie najczęściej przywoływanym przez Lubich okresem liturgicznym. Wymowne są już same hasła tytułowe, w których zawarta jest główna myśl: „Dać życie Jezusowi pośród nas” (1981); „Aby być tym, czym jesteśmy - być miłością” (1982); „Boże Narodzenie z tymi, którzy cierpią” (1986); „Radość, która rozkwita z posłuszeństwa” (1987); „Nie pozwolić Jezusowi umrzeć” (1988); „Budować i odbudowywać wspólnotę" (1990); [Zbliża się Boże Narodzenie...] (1993); „Szczególna winna kiść”19 (1997); „Radość doskonała” (1998); „Nasza relacja do Trzech Osób Boskich" (2001).

Każdy z tych tekstów zasługuje na osobną analizę teologiczno-duchową. Tym niemniej, czytając je jeden po drugim, można zauważyć dwa podstawowe kierunki refleksji Chiary, które przywołują dwa filary duchowości jedności. Pierwszy z nich zawiera się już w haśle z 1981 roku: „dać życie Jezusowi pośród nas”. Tak wyjaśnia je Lubich: „Boże Narodzenie przypomina nam najważniejszy punkt naszej duchowości [...]. To Jezus, który w pewien sposób rodzi się i żyje pomiędzy nami, jeżeli żyjemy miłością wzajemną i ciągle ją odnawiamy. Dawać życie Jezusowi pomiędzy nami - jest naszym najważniejszym obowiązkiem ${ }^{20}$. Jest istotą naszego Ruchu. I może dlatego w tych dniach moją duszę nurtuje myśl, która jest również przestrogą: «Nie możesz sięgać po luksus świętości, jeśli nie ma wśród was Świętego. Nie możesz się łudzić, że staniesz się doskonałą, jeśli nie ma wśród was Doskonałego»"21. Duchowa obecność Jezusa we wspólnocie, zgodnie z obietnica zawartą w Ewangelii (Mt 18,20), jest kontynuacją dzieła wcielenia i czyni święto Narodzenia Pańskiego aktualnym, prawdziwym.

Drugi kierunek refleksji zawiera się w tytule „Boże Narodzenie z tymi, którzy cierpią, a obecny jest także w kilku innych tekstach. Pisze Lubich: „Dzisiaj ciepło Bożego Narodzenia sprawia, że czujemy się wszyscy bardziej rodziną, bardziej jedno między sobą, bardziej braćmi; skłania więc do współdzielenia

${ }^{19}$ Winna kiść (z wł. grappolo) - tym symbolicznym obrazem Lubich określa grono osób, które poszczególni członkowie obejmują swoją apostolską troską, poprzez indywidualny kontakt.

${ }^{20}$ Potwierdzenie tej myśli znajduje się na pierwszej stronie Statutów Generalnych Dzieła Maryi (Ruch Focolari) w formie zatwierdzonej przez Stolicę Apostolską w 1990 roku: „Wzajemna i trwała miłość, która umożliwia jedność i przynosi obecność Jezusa we wspólnocie, stanowi dla osób należących do Dzieła Maryi podstawę ich życia w każdym aspekcie: jest normą norm, fundamentem każdej reguły”. Dzieło Maryi, Statuty Generalne, 11.

${ }^{21}$ Lubich, Vandeleene, Conversazioni in collegamento telefonico, 69. 
wszystkiego: radości i cierpień. Cierpień zwłaszcza z tymi, którzy z powodu różnych okoliczności spędzają to Boże Narodzenie sam na sam z cierpieniem”,22. A na zakończenie dodaje: „życzymy wszystkim, by każde, mniejsze czy większe, napotkane cierpienie potrafili przyjąć z miłością, z wielką miłością, aby ofiarować je Dzieciątku Jezus, które się dzisiaj narodziło, tak jak Mędrcy ofiarowali swoje dary. Będzie to najlepsze kadzidło, najlepsze złoto, najlepsza mirra, jakie możemy złożyć u żłóbka"23. Narodzenie Pańskie objawia Boga, który kocha wszystkich, ale wybiera pośród nich najbardziej ubogich, grzesznych, chorych, zrozpaczonych. Taka logika miłości stanowi dla Chiary wyzwanie, którym konsekwentnie dzieli się z członkami Ruchu: jako chrześcijanie i fokolarini są powołani, aby kochać podobnie jak Bóg.

Dwukrotnie w analizowanych pismach pojawia się nawiązanie do Wielkiego Postu. W 1986 roku Lubich wskazuje jako drogę nawrócenia: „odrodzić się z miłością". W 1987 roku, wychodząc od momentu chrztu jako śmierci dawnego i narodzin nowego człowieka, przypomina, iż duchowe umieranie i powstawanie do życia w Chrystusie jest stałą kondycją chrześcijanina. W tym kontekście proponuje jako motto: „wyrzekać się i kochać”, które tak wyjaśnia: „nie zapominajmy, że charyzmat Ruchu podkreśla szczególny sposób wyrzeczenia [...]. Jest nim: kochać bliźniego, kochać się wzajemnie. Ten, kto kocha, wyrzeka się przede wszystkim szatana, gdyż jego królestwem jest nienawiść, wyrzeka się dóbr, wyrzeka się wielu zbytecznych rzeczy i próżności, ponieważ wszystko, co może, oddaje na rzecz innych"24. Zarówno w okresie Adwentu jak i Wielkiego Postu, czas przygotowania do najważniejszych świąt jest dla Chiary wciąż nowym wezwaniem do większej miłości.

Częste oraz pełne teologicznej i duchowej treści są nawiązania do Wielkanocy. Znajdują się one w przesłaniach: „Lud Wielkanocy” (1982); „Natychmiastowa odpowiedź: wybór preferencjalny Jezusa Opuszczonego" (1984); „Raczej umrzeć niż nie kochać Cię Opuszczonego” (1985); „Odrodzić się z miłością” (1986); „Wyrzekać się i kochać (1987); „Przyjdź, Panie Jezu!” (1989); „Odnowić pakt” (1990); „Aby być ludem Wielkanocy” (1994); „Cztery słowa" (2000). Już w tekście z 1982 roku pojawia się schematyczny opis poszczególnych tajemnic Triduum Paschalnego w świetle duchowości Focolari: „Nowe Przykazanie, wraz z umywaniem nóg, ustanowienie kapłaństwa, które wspominaliśmy w Wielki Czwartek [...]; ustanowienie Eucharystii;

\footnotetext{
${ }^{22}$ Lubich, Vandeleene, Conversazioni in collegamento telefonico, 266.

${ }^{23}$ Tamże, 268.

${ }^{24}$ Tamże, 282.
} 
Testament Jezusa ${ }^{25}$; wielkopiątkowa Męka Jezusa i Jego Opuszczenie; Jezus Zmartwychwstały w dniu Wielkanocy"26. Myśl z roku 2000 dodaje jeszcze rozwinięcie tajemnicy Wielkiej Soboty: jej ikoną jest Maryja, której Chiara nadaje przydomek: Osamotniona ${ }^{27}$.

Tajemnice Triduum Paschalnego mają dla fokolarinów zupełnie wyjątkowe znaczenie ,ze względu na naszą duchowość rozkwitłą z charyzmatu danego nam przez Ducha Świętego [...]. Każdy z tych dni moglibyśmy określić jednym słowem, które od przeszło pięćdziesięciu lat w Ruchu mówi [...], kim powinniśmy być. Są to: Miłość - Wielki Czwartek, Jezus Opuszczony - [...] Wielki Piątek; Maryja - Wielka Sobota; Jezus Zmartwychwstały - Niedziela Wielkanocna"28.

Wielki Czwartek jest dniem, w którym według Ewangelii Jana Jezus wypowiada modlitwę o jedność, stanowiąca podstawę duchowości Focolari. Jednocześnie przypomina ustanowienie Eucharystii, którą Chiara nazywa więzią jedności. W jego kontekście Jezus pozostawia nowe przykazanie miłości wzajemnej, ukazując dzień później jej najwyższą miarę: oddanie życia za przyjaciół. Dla Lubich staje się ono podstawową regułą życia wspólnotowego, która już w pierwszych latach Ruchu znajduje swój konkretny wyraz w tzw. pakcie miłości wzajemnej $^{29}$, odnawianym tego dnia szczególnie uroczyście.

Wielki Piątek przypomina wyłączny wybór Jezusa w Jego bolesnym wołaniu: „Boże mój, Boże mój, czemuś Mnie opuścił?” (Mk 15,34), o którym Chiara pisała już w 1949 roku: „Mam tylko jednego Oblubieńca tu, na ziemi:/Jezusa Opuszczonego;/nie mam innego Boga poza Nim"30. Adoracja krzyża wraz z symbolicznym ucałowaniem go oznacza dla fokolarinów odnowienie tych duchowych zaślubin, deklarację wyłącznej miłości okazywanej dzień po dniu.

${ }^{25}$ To określenie Lubich odnosi się do modlitwy arcykapłańskiej Jezusa, a szczególnie do tej prośby, która stanowi centrum duchowości Focolari: ,aby wszyscy stanowili jedno, jak Ty, Ojcze, we Mnie, a Ja w Tobie" (J 17,21). Por. Chiara Lubich, Jedność (Ląka-Warszawa: Fundacja Mariapoli, 2016), 21-23.

${ }^{26}$ Lubich, Vandeleene, Conversazioni in collegamento telefonico, 78.

27 To imię nadane Maryi, która w pobożności chrześcijańskiej znana jest jako Bolesna, w duchowości Chiary odpowiada imieniu „Opuszczony” używanemu w odniesieniu do Jezusa na krzyżu.

${ }^{28}$ Lubich, Vandeleene, Conversazioni in collegamento telefonico, 588.

${ }^{29}$ Pakt miłości wzajemnej to zobowiązanie wypowiadane we wspólnocie, iż jej członkowie będą się starać, z pomocą Bożą, o taką miłość, która zawiera intencjonalnie gotowość oddania życia jedni za drugich. Por. Chiara Lubich, Mitość wzajemna (Warszawa: Fundacja Mariapoli, 2014), 66-71.

${ }^{30}$ Lubich, Charyzmat jedności, 148. 
W Wielką Sobotę Chiara wspomina Maryję: „Niezgłębiona otchłań smutku i nieskończonej udręki? Tak, ale Ona stoi o własnych siłach, stając się niezwykłym przykładem, arcydziełem wszystkich cnót. [...] Nie poddaje się cierpieniu. Czeka" ${ }^{31}$. Trwając samotnie na zażyłej rozmowie z Ojcem, staje się Ona drogą do doskonałości, ,gwarancją świętości, stałym źródłem jedności z Bogiem, naczyniem przepełnionym radością" 32 . Jak przypominają Statuty Generalne, jest tym samym Matką jedności, gdyż swoim życiem pokazuje, jak „tracić wszystko i wszystkich, aby współdziałać na rzecz jedności ludzi z Bogiem i między sobą"33.

Niedziela Wielkanocna jest „tryumfem Jezusa Zmartwychwstałego, który znamy i który przeżywamy także i my w naszej małości, osobiście, po objęciu opuszczenia lub kiedy zjednoczeni naprawdę w Jego imię doświadczamy skutków Jego życia, owoców Jego Ducha" ${ }^{34}$. Opuszczenie i śmierć, nieuniknione dla ludzkiej kondycji, stają się dzięki spotkaniu z Chrystusem przejściem, prawdziwą Paschą, a wspólnota żyjąca w ten sposób wspomnianym już „ludem Wielkanocy”35. Chiara jest przekonana, że dzięki obietnicy dotyczącej obecności Jezusa wśród uczniów zgromadzonych w Jego imię (por. Mt 18,20), zmartwychwstanie jest nie tylko przedmiotem wiary, ale namacalnym doświadczeniem, które pozwala powtórzyć za Marią Magdaleną: „,widzieliśmy Pana” (por. J 20,18) ${ }^{36}$. „Tak, odkryliśmy Go w świetle, którym nas oświecił; dotknęliśmy Go w odczuciu pokoju, którym nas napełnił; słyszeliśmy Jego głos w głębi serca; zasmakowaliśmy Jego niezrównanej radości" ${ }^{37}$. Prawda wiary staje się zatem osobistym i wspólnotowym doświadczeniem, które niesie ze sobą liczne łaski i dary duchowe.

Kolejną uroczystością, która wybrzmiewa często w analizowanych pismach, jest Zesłanie Ducha Świętego. Odnoszą się do niego następujące tytuły: „Zbawiać i powracać” $(1984)^{38}$; „Zapierajmy się siebie, aby pozwolić

${ }^{31}$ Lubich, Vandeleene, Conversazioni in collegamento telefonico, 590.

${ }^{32}$ Lubich, Charyzmat jedności, 208.

33 Dzieło Maryi, Statuty Generalne, art. 8 p. 9.

${ }^{34}$ Lubich, Vandeleene, Conversazioni in collegamento telefonico, 590.

35 Por. tamże, 78-80.

${ }^{36}$ Por. Chiara Lubich, Michel Vandeleene, Egli è vivo! La presenza del Risorto nella comunità cristiana (Roma: Città Nuova, 2006).

${ }^{37}$ Lubich, Vandeleene, Conversazioni in collegamento telefonico, 590.

${ }^{38}$ W przywołanym tekście Lubich rozwija myśl dotyczącą Zesłania Ducha Świętego, ale przywołuje również inne święta tego okresu: Wniebowstąpienie, Uroczystość Trójcy Przenajświętszej, Najświętszego Ciała i Krwi oraz wspomnienie Niepokalanego Serca Maryi. Por. Lubich, Vandeleene, Conversazioni in collegamento telefonico, 155-157. 
Duchowi Świętemu swobodniej działać” (1985); „Ty tego chcesz, ja również tego chcę” (1990); „Święci z miłości” (1991). Refleksja Chiary i płynące z niej zachęty wynikają przede wszystkim z wdzięczności wobec Ducha Świętego, który jest dawcą wszystkich charyzmatów w Kościele, również charyzmatu jedności. Pielęgnować i umacniać więź z Nim znaczy więc pozwolić się prowadzić drogą, jaką On sam otworzył, być wiernym pierwotnemu, oryginalnemu powołaniu. Jednocześnie, On jest źródłem i sprawcą świętości, a zatem szczególnym protektorem „świętej podróży”. Lubich dzieli się owocami swojego wewnętrznego doświadczenia, które staje się także udziałem innych: „aby Duch Święty mógł działać, potrzeba naszej współpracy [...]. Doświadczamy tego codziennie: każde cięcie, każde oczyszczenie, każde «nie» powiedziane naszemu «ja» - jest źródłem nowego światła, pokoju, radości, miłości, wolności wewnętrznej; jest bramą otwartą dla Ducha Świętego"39. Droga duchowa, każdy jej fragment na poszczególnych etapach życia, prowadzi zawsze przez spotkanie z Jezusem Opuszczonym aż do Pięćdziesiątnicy: takie jest nieustanne odkrycie Chiary i płynące zeń postanowienie, dzielone z innymi, aby kochać Boga w sposób coraz bardziej doskonały.

Odczytując „świętą podróż” z perspektywy liturgicznej, należy jeszcze zwrócić uwagę na wątki maryjne pojawiające się w analizowanych tekstach. Zasadniczo nie spotyka się w nich bezpośrednich nawiązań do poszczególnych świąt, liczne są natomiast aluzje do maja jako miesiąca poświęconego Matce Bożej ${ }^{40}$. Znaleźć je można w następujących przesłaniach: „Maryja, nasz wzór” (1984); „W ten sposób Maryja staje się naszą Matką” (1985); „Maryja, wychowawczyni świętych” (1986) i „Kochać nie oszczędzając się” (1986); „Miłość, którą widać” (1989); „Być dla wszystkich przyczyną radości” (1990). Miesiąc maj jest dla Chiary okazją, aby uczyć się od Maryi czystej miłości do Boga i ludzi oraz powierzyć Jej wstawiennictwu konkretne postanowienia na drodze do świętości: chętnie przy tej okazji odwiedza sanktuaria maryjne. Pobożność tę charakteryzuje pragnienie naśladowania życia Matki, której - ze względu na duchowość Focolari - czuje się uprzywilejowaną córką.

Przywołane w opisie „świętej podróży” odniesienia liturgiczne wskazują na zasadnicze cechy duchowości Lubich, odpowiadające treści wyznawanych przez Kościół tajemnic wiary. Jej doświadczenie duchowe jest chrystocentryczne i trynitarne, gdyż wypływa ze spotkania z Bogiem objawiającym się we wcielonym Synu; eklezjalne i wspólnotowe, jako odpowiedź na modlitwę

\footnotetext{
39 Tamże, 199.

${ }^{40}$ Pojawia się także nawiązanie do roku maryjnego (1987).
} 
arcykapłańską Jezusa; oparte na Biblii; misyjne ze względu na doniosłość świadectwa życia; głęboko maryjne, gdyż patrzy na Maryję jako na wzór osoby, która wypełniając wolę Bożą, umiała uczynić całe swoje życie ofiarą Jemu miłą ${ }^{41}$. Bez wątpienia, dominujące - jeśli chodzi o częstotliwość i o wagę - są odwołania do tajemnicy Wcielenia i Paschy, podczas gdy inne wydarzenia liturgiczne zdają się pozostawać w tle. Tendencja ta wyraża głęboki sens misterium Chrystusa uobecnianego przez cały rok kościelny ${ }^{42}$, który - jak stwierdza Katechizm Kościoła Katolickiego - ,jest rozwinięciem różnych aspektów jedynego Misterium Paschalnego. W sposób szczególny odnosi się to do cyklu świąt skupionych wokół misterium Wcielenia (Zwiastowanie, Narodzenie Pańskie, Objawienie Pańskie), które wspominają początek naszego zbawienia i komunikuja nam pierwociny Misterium Paschalnego" (KKK 1171). Tajemnice życia Chrystusa, objawione w pełni w wydarzeniach Triduum Sacrum, a zapoczątkowane w Jego przyjściu na świat, streszczają w sobie całą ekonomię zbawienia i pozwalają odkryć jej teologiczne i duchowe znaczenie.

\section{KONTEMPLACJA TAJEMNIC JEZUSA CHRYSTUSA W ŚWIETLE DUCHOWOŚCI JEDNOŚCI}

Droga do świętości we wspólnocie, jaką Lubich proponuje członkom Ruchu, składa się z elementów charakterystycznych dla życia chrześcijańskiego pośród świata, który staje się ,polem i narzędziem ludzi świeckich w realizacji ich chrześcijańskiego powołania, sam bowiem przeznaczony jest na to, by wysławiać Boga Ojca w Chrystusie" (ChL 15). Wydarzenia cywilne i religijne, aktywność apostolska i proste gesty życia codziennego, znajdują swoje miejsce w duchowym doświadczeniu Chiary - którego świadectwem są analizowane tu pisma - jako typowe komponenty procesu uświęcenia. Natomiast odniesienia do poszczególnych okresów roku liturgicznego, wplecione w sposób naturalny w kalendarz świecki, wskazują na głębokie zakorzenienie tej duchowości w całej tajemnicy Jezusa Chrystusa i stanowią eklezjalny kontekst uniwersalnej działalności Ruchu. W istocie, życie Kościoła i każdej

${ }^{41} \mathrm{Na}$ takie cechy typowe dla duchowości liturgicznej wskazuje Castellano Cervera, por. Jesús Castellano Cervera, „Liturgia, teologia spirituale e spiritualità”, Teresianum 52(2001), 1-2: 528-531.

${ }^{42}$ Por. Bogusław Migut, „Rok liturgiczny aktualizacją misterium Chrystusa”, Roczniki Liturgiczne 56(2009), 1: 271-296. 
pojedynczej wspólnoty, choć otwarte na historię świecką oraz jej uwarunkowania, zarówno te zaplanowane jak i te nieprzewidziane, jest zakotwiczone w celebracji misterium Chrystusa, w którym teraźniejszość i przyszłość znajdują swe ostateczne wyjaśnienie ${ }^{43}$.

W duchowości chrześcijańskiej, szczególnie tej typowej dla osób świeckich, „liturgia nie jest akcją oderwaną od ludzkiego życia dokonującego się w czasie, w ustawicznie zmieniających się warunkach, ale [...] życie to kształtuje, $[\ldots]$ pozwala człowiekowi odkryć i uznać boską rangę wszechstworzenia, odkryć i uznać liturgię wszechstworzenia, liturgię kosmiczną, oraz przeżyć zbawczą wartość także swego doczesnego zaangażowania w budowę lepszego świata i nadać temu zaangażowaniu liturgiczny charakter w sensie liturgii życia"44. Codzienne działanie, o ile zakorzenione jest w głębokiej komunii z Bogiem, staje się przedłużeniem liturgii i uświęca rzeczywistość stworzoną we wszystkich jej wymiarach. Właściwa chrześcijaństwu „kontemplacja tajemnicy dąży - w najbardziej dosłownym znaczeniu - do realizacji tego, czym jest ta tajemnica" 45 .

$\mathrm{Na}$ takie rozumienie misterium Chrystusa na przestrzeni roku liturgicznego wskazują pisma Lubich stanowiące zapis jej świadomego i wytrwałego podążania do świętości, rozumianej jako „doskonałość miłości” ${ }^{46}$. Niewiele jest w nich bezpośrednich odniesień do rytu celebracji poszczególnych wydarzeń, gdyż ich celem jest raczej zachęta i wzajemna pomoc, aby przełożyć wyznawaną tajemnicę na codzienne życie, starając się upodobnić w nim coraz bardziej do Pana. O tym przedłużeniu liturgii w każdym ludzkim działaniu, podejmowanym ze względu na Boga i Jego powszechny zamysł miłości, świadczy również stałe odniesienie duchowości Focolari do obietnicy Jezusa: „gdzie są dwaj albo trzej zebrani w imię moje, tam jestem pośród nich” (Mt 18,20). Tradycyjnie na tę formę obecności Chrystusa w Kościele wskazuje się przede wszystkim w kontekście wspólnej celebracji sakramentów (por. KL 7), podczas gdy Chiara czyni je podstawą duchowości jedności w każdym aspek-

43 Jesús Castellano Cervera, L’anno liturgico. Memoriale di Cristo e mistagogia della Chiesa con Maria Madre di Gesù (Roma: Centro di Cultura Mariana „Madre della Chiesa” (1991): 10 .

${ }^{44}$ Walerian Słomka, „Liturgia a duchowość chrześcijańska”, Ruch Biblijny i Liturgiczny 22(1969), 4-5: 244.

${ }^{45}$ Louis Bouyer, Wprowadzenie do życia duchowego. Zarys teologii ascetycznej $i$ mistycznej (Warszawa: PAX, 1982), 77.

${ }^{46}$ Dzieło Maryi, Statuty Generalne, art. 5. 
cie życia ${ }^{47}$. Czuje się przynaglona, i zachęca do tego innych, aby całe swoje istnienie uczynić konkretną odpowiedzią na miłość Boga, udzielającą się w ekonomii zbawienia. Wydaje się, że oryginalność liturgicznej duchowości Focolari polega na tym niestrudzonym dążeniu, aby usłyszane Słowo i znaki liturgiczne, zawierające tajemnicę Boga objawioną w Chrystusie, przełożyć na codzienne życie.

Myśl, iż „człowiek jest drogą Kościoła” (RH 14), współbrzmi z przekonaniem Chiary, iż uprzywilejowaną drogą do Boga jest człowiek: bliźni. „Do Boga przez brata" 48 , przypomina ona członkom Ruchu w roku 1982, u progu Adwentu. Myśl tę powtarza na wiele sposobów, podkreślając rozmaite formy jej aktualizacji w odniesieniu do specyficznych wydarzeń z życia osobistego i wspólnotowego. Rozważając zbawcze działanie Boga w historii, od zapowiedzi Wcielenia aż po Zmartwychwstanie i Zesłanie Ducha Świętego, Lubich odkrywa wciąż na nowo różne aspekty Jego miłości, która budzi w niej pragnienie konkretnej odpowiedzi. Przekonuje się, że najbardziej skuteczną i bezpośrednią formą takiej odpowiedzi jest okazanie podobnej miłości bliźniemu. W takiej postawie dostrzega również sedno ascezy chrześcijańskiej: wysiłek wewnętrzny skierowany na to, aby kochać drugiego, sprawia, że w duszy rozwijają się poszczególne cnoty, a wygasa egoizm i wypływające zeń wady.

„Wśród tysięcy dróg, które mogliśmy obrać, [Duch Święty] wskazał nam tę jedną drogę - serce chrześcijaństwa; to przykazanie [miłości wzajemnej], do którego urzeczywistnienia zmierzają wszystkie inne przykazania. I stąd gorące pragnienie [...]: żyć tym przykazaniem coraz lepiej, urzeczywistniać je coraz doskonalej, skupiając na tym cały wysiłek ascetyczny chrześcijańskiego wyrzeczenia, który powinien przeniknąć nasze życie, ponieważ ten sposób kochania nie jest czymś zwyczajnie ludzkim, lecz nadprzyrodzonym"49. Droga do świętości oznacza zatem nieustanne nawrócenie na nowe

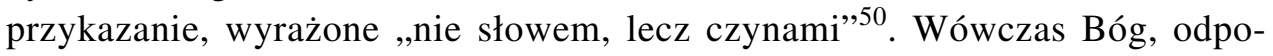

${ }^{47}$ Odniesienie do Mt 18,20, jak zauważa Pasquale Foresi, niezwykle rzadko pojawia się we wcześniejszych dokumentach Kościoła, natomiast powraca wyraźnie w nauczaniu Soboru Watykańskiego II, co wskazuje na oryginalny charakter i aktualność duchowych intuicji Lubich w odpowiedzi na znaki czasu. Por. Pasquale Foresi, Dio ci chiama. Conversazioni sulla vita cristiana (Roma: Città Nuova, 2003), 45-46.

${ }^{48}$ Lubich, Vandeleene, Conversazioni in collegamento telefonico, 99.

49 Tamże, 171-172.

50 Tamże, 172. 
wiadając na taką predyspozycję, przychodzi z łaską i pozwala doświadczyć swej obecności, poprzez dar pokoju, radości, wewnętrznego światła ${ }^{51}$.

Zdecydowane postanowienie dążenia do świętości rodzi się w Lubich jako odpowiedź na rozważanie woli Bożej. W jej rozeznawaniu szczególną rolę odgrywa autentyczna więź z Kościołem, a jej wyrazem jest również droga przez rok liturgiczny. Chiara, o czym świadczą jej pisma, doświadcza tego ciągłego uobecniania się dzieła zbawienia w życiu wspólnoty wierzących. Warto przy tym zauważyć, że w łonie zakorzenionego w Kościele katolickim Ruchu Focolari są także chrześcijanie innych wyznań, a zatem przeżywający tajemnice Chrystusa w odmiennym rytmie i według różnych tradycji, a wśród jego sympatyków są także wyznawcy innych religii. Wszyscy oni, we właściwy sobie sposób, uczestniczą w duchowej drodze Chiary, kierują się jej doświadczeniem dzielonym podczas konferencji telefonicznych, włączając się w przedziwny sposób w życie Kościoła powszechnego.

Typowa dla Chiary Lubich droga jedności ze swej natury wskazuje na eklezjalność doświadczenia chrześcijańskiego. Dokonuje się ono we wspólnocie zgromadzonej w imię Chrystusa, który staje pośród ludzi, aby wprowadzić ich w swoją synowską komunię z Ojcem. Z takiego doświadczenia wypływa świadectwo, jako wewnętrzne przynaglenie do dzielenia się otrzymanymi z łaski dobrami. W historii Chiary kształtuje się ono jako oryginalna praktyka: są to krótkie myśli duchowe opatrzone mottem z konkretnym postanowieniem, przekazywane regularnie członkom Ruchu. Analiza tych wybranych przesłań, które odnoszą się bezpośrednio do poszczególnych wydarzeń i okresów roku liturgicznego, pozwala scharakteryzować bliżej doświadczenie Lubich i jego kontekst eklezjalny.

$\mathrm{Na}$ przestrzeni ponad dwudziestu lat zmienia się frekwencja konferencji telefonicznych, a wraz z nią pewne akcenty tematyczne. Uderza natomiast stałość, jeśli chodzi o wysiłek ascetyczny podejmowany niezmiennie jako wydoskonalenie miłości braterskiej, która jawi się jako najwłaściwsza droga do zjednoczenia z Bogiem. Z kontemplacji poszczególnych tajemnic Chrystusa Chiara konsekwentnie odczytuje nowe wezwanie do nawrócenia i podejmuje je w sposób niezwykle konkretny. Nie zawsze główna myśl odnosi się wprost

\footnotetext{
51 Por. tamże, 590.
} 
do kontekstu liturgicznego, czasem jej źródłem są okoliczności zewnętrzne czy inne przeżycia wewnętrzne. Natomiast tym, co powraca zawsze i z nieustającą siłą, jest pragnienie odczytania Bożego działania w duszy i pomiędzy ludźmi. Dla Lubich, z perspektywy powołania do jedności realizowanego pośród świata, wszystko staje się materią uświęcenia, a ,szczęśliwi [są ci], którzy od Ciebie otrzymują pomoc, gdy świętą podróż odbyć zamierzyli w sercu" (Ps 84,6).

\section{BIBLIOGRAFIA}

Abignente, Lucia. „SANTI PER AMORE, SANTI CON GLI ALTRI. Il cammino alla santità nel pensiero e nella testimonianza di Chiara Lubich". Duchowość w Polsce 14(2012): 287-300.

Bouyer, Louis. Wprowadzenie do życia duchowego. Zarys teologii ascetycznej i mistycznej. Warszawa: PAX, 1982.

Castellano Cervera, Jesús. L'anno liturgico. Memoriale di Cristo e mistagogia della Chiesa con Maria Madre di Gesù. Roma: Centro di Cultura Mariana „Madre della Chiesa”, 1991.

Castellano Cervera, Jesús. „Liturgia, teologia spirituale e spiritualità”. Teresianum 52(2001), 1-2: 513-533.

Dzieło Maryi. Statuty Generalne, 2007.

Folonari, Giulia. Lo spartito scritto in cielo. Cinquant'anni con Chiara Lubich. Roma: Città Nuova, 2012.

Foresi, Pasquale. Dio ci chiama. Conversazioni sulla vita cristiana. Roma: Città Nuova, 2003. Jan Paweł II. Adhortacja apostolska Christifideles laici, 1988 (skrót: ChL).

Jan Paweł II. Encyklika Redemptor hominis, 1979 (skrót: RH).

Katechizm Kościoła Katolickiego, 1994 (skrót: KKK).

Lubich, Chiara. Charyzmat jedności. Kraków: Wydawnictwo M; Fundacja Mariapoli, 2007.

Lubich, Chiara. Diario 1964/65. Roma: Città Nuova, 1985.

Lubich, Chiara. Jedność. Łąka-Warszawa: Fundacja Mariapoli, 2016.

Lubich, Chiara. Miłość wzajemna. Warszawa: Fundacja Mariapoli, 2014.

Lubich, Chiara, Fabio Ciardi. Parole di Vita. Roma: Città Nuova, 2017.

Lubich, Chiara, Michel Vandeleene. Conversazioni in collegamento telefonico. Roma: Città Nuova, 2019.

Lubich, Chiara, Michel Vandeleene. Egli è vivo! La presenza del Risorto nella comunità cristiana. Roma: Città Nuova, 2006.

Migut, Bogusław. „Rok liturgiczny aktualizacją misterium Chrystusa”. Roczniki Liturgiczne 56(2009), 1: 271-96.

Rossé, Gérard. „Santità e santificazione negli scritti di Chiara Lubich alla luce di s. Paolo”. Nuova Umanità 19(1997), 3-4): 377-386.

Słomka, Walerian. „Liturgia a duchowość chrześcijańska”. Ruch Biblijny i Liturgiczny 22(1969), 4-5: 239-248.

Sobór Watykański II. „Konstytucja o liturgii świętej”. W Konstytucje. Dekrety. Deklaracje. Poznań: Pallottinum, 2002 (skrót: KL).

Wasiutyńska, Katarzyna. „Święty pomiędzy nami... Ruch Focolari”. Duchowość w Polsce 14(2012): 90-96. 


\section{TAJEMNICE JEZUSA CHRYSTUSA W ROKU LITURGICZNYM A „ŚWIĘTA PODRÓŻ”. ANALIZA WYBRANYCH PISM CHIARY LUBICH}

\section{S t r e s z c z e n i e}

Począwszy od roku 1981 aż do 2004, Chiara Lubich w regularnych konferencjach telefonicznych dzieliła się swoim doświadczeniem duchowym z członkami Ruchu Focolari, zachęcając ich do wspólnego podążania do świętości, zgodnie ze słowami psalmisty: „Szczęśliwi, którzy od Ciebie otrzymuja pomoc, gdy świętą podróż odbyć zamierzyli w sercu" (Ps 84,6). Celem niniejszego artykułu jest analiza tych przesłań w odniesieniu do przywołanych w nich okresów cyklu liturgicznego oraz określenie, w jakiej mierze kontemplacja tajemnic Jezusa Chrystusa w ciągu całego roku może wpłynąć na proces coraz pełniejszego upodobnienia się do Niego.

Słowa kluczowe: Chiara Lubich; rok liturgiczny; święta podróż; konferencje telefoniczne. 